\title{
GC-MS ANALYSIS AND BIOLOGICAL ACTIVITY OF ESSENTIAL OIL OF FRUITS, NEEDLES AND BARK OF PINUS PINEA GROWN WILDLY IN JORDAN
}

\author{
BAHA HALUB ${ }^{1}$, ASHOK K. SHAKYA ${ }^{1 *}$, ZAHA A. ELAGBAR ${ }^{1}$ \\ and RAJASHRI R. NAIK ${ }^{2}$
}

\author{
${ }^{1}$ Department of Pharmacy, Faculty of Pharmacy, Al-Ahliyya Amman University, \\ P.O. Box-263, Amman-19328, Jordan \\ ${ }^{2}$ Department of Medical Laboratory Sciences, Faculty of Allied Medical Sciences, \\ Al-Ahliyya Amman University, P.O. Box-263, Amman-19328, Jordan
}

\begin{abstract}
Essential oils from needles, fruits and bark were extracted from Pinus pinea L. (stone pine) grown wildly in Jordan. The chemical composition, antibacterial activity, antioxidant activity of essential oils were evaluated. The chemical compositions were identified using Gas-Chromatography-Mass spectrometry (GCMS) and retention indices (Van den Dool \& Kratz). The results show that the essential oil obtained from needles composed mainly of guaiol (12.7\%), limonene (11.42\%), and $\beta$-caryophyllene (7.61\%), while fruit contains limonene $(32.56 \%)$, and $\alpha$-pinene $(6.78 \%)$. The essential oils from barks were rich in $\beta$-caryophyllene $(16.51 \%)$, limonene $(14.83 \%)$, caryophyllene oxide $(11.83 \%)$, and longifolene $(7.51 \%)$. In vitro, the antibacterial activity of the essential oils was evaluated using the agar-well diffusion method against three different strains of bacteria (Gram-positive bacteria: Staphylococcus aureus and Gram-negative bacteria: Klebsiella pneumoniae and Escherichia coli). The results indicated that essential oil exhibited appreciable antibacterial activity against $S$. aureus. The essential oil from fruit exhibited weak antibacterial activity against $E$. coli and $K$. pneumoniae. Essential oils of $P$. pinea showed appreciable antioxidant activity in-vitro.
\end{abstract}

Keywords: Essential oils, Pinus pinea, antioxidant activity, antibacterial activity

Pinus pinea L. (Italian stone pine) belongs to the family Pinaceae which consists of 250 species of the plants. In recent classification $P$. halepensis, $P$. brutia, $P$. heldreichii, $P$. pinaster, $P$. pinea, $P$. canariensis, and $P$. roxburghii are grouped within the subsection of pinaster, also known as the Mediterranean pine group $(1,2)$. Pinus pinea is widely spread in the northern hemisphere, especially in the Mediterranean region, Europe, Asia, South Africa, and North and Central America (3). P. halepensis and $P$. brutia can be adopted in different environmental conditions.

In Arab countries, it is usually located in the mountain regions of Lebanon, Syria, Algeria, Libya, and the Moroccan countryside. It is abundantly grown in Jordan reaching to a height of $30 \mathrm{~m}$. Due to its medicinal properties, the essential oils of Pinus pinea have been used in folk medicine for the treatment of skin diseases such as eczema and psoriasis and as an analgesic and anti-inflammatory agent.
The essential oil from the cones and needles of Pinus pinea showed significant wound healing activity and had a remarkable effect on rheumatic pain (4). Essential oils derived from Pinus pinea grown in Lebanon (5) showed cytotoxic activities against drug-sensitive CCRF/ADR5000 leukemia cells with $\mathrm{IC}_{50}$ values ranging from $29.5 \mu \mathrm{g} / \mathrm{mL}$ to $61.4 \mu \mathrm{g} / \mathrm{mL}$.

The volatile composition of Pinus pinea L. needles (6) showed significant variation in the chemical constituents. Several studies have shown a significant difference in the volatile composition of the essential oil which may be due to the geographic location, climatic conditions, and time of collection. The variation in the chemical constituents may also affect its antioxidant activity. Scavengers like flavonoids, polyphenols, and phenolic acids are excellent antioxidant compounds that scavenge free radicals like peroxide and hydroperoxide, and thus inhibit the oxidative stress that causes diseases (7).

* Corresponding author: e-mail: ashokkumar2811@gmail.com 
Synthetic drugs and synthetic antioxidants produce adverse effects apart from their free radical scavenging activity (8). Consumption of natural food supplements, phytochemicals, and natural antioxidants can significantly lower the adverse effects. Food supplements of natural origin are the best way to combat these adverse effects (9). The purpose of this study was to investigate the chemical constituents present in the essential oils from the needles, fruits, and bark of Pinus pinea L. that grow wild in Jordan and to evaluate the antioxidant and antibacterial activity.

\section{MATERIAL AND METHODS}

\section{Chemicals}

Modified Griess reagent, DPPH·, ferrozine, sodium nitroprusside, $\beta$-carotene, and other chemical were purchased from Sigma-Aldrich (USA) and used without purification.

\section{Plant material}

The needles, fruits and barks of $P$. pinea species were collected during July and August in 2015 from different trees in Jordan, planted in AlSalt governorate (Al-Ahliyya Amman University), and in Amman governorate (Iraq Al-Ameer, Amman). The plants were identified by Taxonomist (Dr. Dawud Mohammad Al-Eisawi, University of Jordan, Amman).

\section{Isolation of the essential oils}

The air-dried needles, fruits and bark of the collected plant were ground to about $0.8 \mathrm{~mm}$ particle size (18-20 mesh). Ground plant material (200 g) was accurately weighed transferred to a doublenecked round-bottomed flask (2 L). Distilled water was added to it $(1.25 \mathrm{~L})$ and it was subjected to hydro-distillation using Clevenger-type apparatus for 3 hours $(n=3)$. The hydro-distilled essential oils were collected and dried over anhydrous sodium sulfate. The essential oils were transferred to amber colored vials, flushed with nitrogen, sealed and stored in a refrigerator until required.

\section{Analysis of essential oils (EOs)}

Analysis of EOs and fraction were carried out using Varian Chrompack CP-3800 GC/MS/MS2200 equipped with a split-spitless injector, DB$5 \mathrm{MS}$ fused silica column (5\% phenyl, $95 \%$ polydimethylsiloxane $30 \mathrm{~m} \times 0.25 \mathrm{~mm}$, film thickness 0.25 $\mu \mathrm{m})$. A linear temperature program was used to separate the different oil components. Temperature programming was applied at $3^{\circ} \mathrm{C} / \mathrm{min}$ heating rate start- ing from $60^{\circ} \mathrm{C}$ (initial temperature) to $250^{\circ} \mathrm{C}$ (final temperature) and held at $250^{\circ} \mathrm{C}$ for $5 \mathrm{~min}$ with a total run time of $70 \mathrm{~min}$. Injector temperature was $250^{\circ} \mathrm{C}$ with a split ratio of $1: 10$; injection volume $(1 \mu \mathrm{L})$, carrier gas: helium; MS source temperature/detector temperature: $250^{\circ} \mathrm{C}$, ionization energy (EI): $70 \mathrm{eV}$; amu gain -492, amu offs. -67 , ionization current 60 $\mu \mathrm{m}$; scan range 40-400 amu.

Mass spectrum of every chemical constituent was compared with corresponding reported spectrum (in NIST, Wiley Mass Spectral Database -1995 and ADAMS-2007 libraries) for GC-MS and published references. Identification of compounds was also confirmed by comparing their retention indices (RI) relative to n-alkanes $\left(\mathrm{C}_{8}-\mathrm{C}_{20}\right)$ with reported values in the literature including Adam's library. Samples were analyzed in triplicate.

\section{Antimicrobial activity}

The antibacterial activity of the essential oils, fraction and isolated compound was evaluated by agar diffusion method against three bacterial species, two gram-negative strains (Klebsiella pneumoniae and Escherichia coli ATCC 8739) and one-gram positive strain (Staphylococcus aureus ATCC 6538a). Samples were vortexed, circular discs of filter paper (6 $\mathrm{mm})$ were sterilized and placed in the samples (33\% EO in $30 \%$ aqueous DMSO (dimethylsulfoxide) for soaking $(24 \mathrm{~h})$. The plates were inoculated with bacteria and the samples were placed over the media. The plates were incubated at $37.0 \pm 0.5^{\circ} \mathrm{C}$ for 24-48 h. After the desired incubation time, the diameter of the zone of inhibition was measured. DMSO (30\%) was used as negative control and different antibiotics discs were used as standard. The antibiotics were tobramycin (30 $\mu \mathrm{g} / \mathrm{disc})$, penicillin $\mathrm{G}$ (10 U/disc), lincomycin $(2 \mu \mathrm{g} / \mathrm{disc})$, chloramphenicol (30 $\mu \mathrm{g} / \mathrm{disc})$ and cefaclor $(30 \mu \mathrm{g} / \mathrm{disc})$.

\section{DPPH free radical scavenging activity ${ }^{10}$}

The free-radical scavenging activity of the EOs was measured as a decrease in the absorbance of methanol solution of 2,2-diphenyl-1-picrylhydrazyl (DPPH). A stock solution of DPPH $(0.002 \%$ w/v) was prepared in methanol and different concentrations of the EOs were added $(2-250 \mu \mathrm{g} / \mathrm{mL})$. After incubation at room temperature for $30 \mathrm{~min}$, the pale pink color developed was measured at $517 \mathrm{~nm}$ using a spectrophotometer and compared with the standard (1-100 $\mu \mathrm{g} / \mathrm{mL}$ ascorbic acid). Free radical scavenging activity (9) was expressed as the percentage inhibition calculated using the following formula:

$\%$ Free radical scavenging activity $=\left[1-\frac{A b s_{\text {sample }}}{A b s_{\text {control }}}\right] \times 100$ 


\section{Ferrous ion-chelating activity}

The samples were estimated for the ferrous ion-chelating activity as described by Chua et al. (11). Briefly, $750 \mu \mathrm{L}$ of the sample in methanol mixture $(2-250 \mu \mathrm{g} / \mathrm{mL})$ were incubated with $50 \mu \mathrm{L}$ ferrous chloride solution $\left(\mathrm{FeCl}_{2}\right)(2 \mathrm{mM})$. The reaction was initiated by the addition of $50 \mu \mathrm{L}$ ferrozine solution $(5 \mathrm{mM})$ into the mixture and allowed to stand for 10 minutes in dark. The absorbance of the reaction mixture was measured at $562 \mathrm{~nm}$. Rutin was used as a positive control in this assay.

\section{Nitric oxide radical scavenging activity ${ }^{12}$}

The aqueous sodium nitroprusside (SNP) solution reacts with oxygen and generates nitrite ions, these ions can be quantitated by Modified Griess reagent. In brief, the reaction mixture contained 10 $\mathrm{mM}$ SNP $(0.25 \mathrm{~mL})$, phosphate-buffered saline $(\mathrm{pH}$ $7.4,0.40 \mathrm{~mL}$ ) and various concentrations of the test solution $(0.10 \mathrm{~mL})$ in test tubes, after incubation at $25^{\circ} \mathrm{C}(150 \mathrm{~min}$.), the $0.25 \mathrm{~mL}$ of Griess reagent $(1 \mathrm{x}$, Sigma-Aldrich, USA) was added. The color generated during the diazotization of nitrite ions was measured spectrophotometrically at $546 \mathrm{~nm}$. Quercetin (10-175 $\mu \mathrm{g} / \mathrm{mL})$ was used as a standard compound for comparison.

\section{$\beta$-carotene bleaching (BCB) Assay ${ }^{13}$}

A solution of $\beta$-carotene was prepared by dissolving $5 \mathrm{mg}$ of $\beta$-carotene in $50 \mathrm{~mL}$ of chloroform. An aliquot of the $3 \mathrm{~mL}$ was added to $40 \mathrm{mg}$ linoleic acid and $400 \mathrm{mg}$ of tween 40. It was mixed and set aside for 2 minutes. The chloroform was evaporated off using nitrogen gas. The residue was reconstituted in $100 \mathrm{~mL}$ of distilled water using vortex. Immediately after preparation, the absorbance of this solution was recorded at 470 and $700 \mathrm{~nm}$. Different solutions of oil $(50 \mu \mathrm{g} / \mathrm{mL}$ to $1000 \mu \mathrm{g} / \mathrm{mL})$ were prepared in methanol (with the aid of $0.05 \%$ Tween-40). $\beta$-Carotene-linoleic acid emulsion (1 $\mathrm{mL})$ was mixed with different solutions of oil $(0.25$ $\mathrm{mL}$ ). All the solutions (control and test) were capped and incubated $\left(50^{\circ} \mathrm{C}\right)$ for 1 hour. The control sample contains anequivalent amount of methanol $(0.05 \%$ Tween-40). The absorbance of the solutions $\left(\lambda_{470}\right.$ and $\left.\lambda_{700} \mathrm{~nm}\right)$ was determined after $60 \mathrm{~min}$. All determination was carried out in triplicate; the degradation rate (DR) and antioxidant activity were calculated.

\footnotetext{
Degradation rate $(\mathrm{DR})$ of $\beta$-carotene $=$ $\operatorname{Ln}\left(\mathrm{A}_{\text {initial }} / \mathrm{A}_{\text {sample }}\right) / 60$

Antioxidant activity $(\%)=\left[1-\frac{\text { Degradation rate of sample }}{\text { Degradation rate of control }}\right] \times 100$
}

\section{Statistical analysis}

Results are expressed as mean \pm standard deviation (SD). Graph-Pad Prism 5 (San Diego, CA, USA) for Windows was used for statistical analyses of experimental data.

\section{RESULT AND DISCUSSION}

\section{Chemical composition of essential oils}

The simultaneous use of mass spectroscopy and arithmetic retention index (14) correlation allowed for unequivocal identification of more than $72.9,78.2$ and $75.6 \%$ of the components of the essential oils obtained from needles, fruits and bark of Pinus pinea under study which are determined by the GC-FID and GC-MS. The essential oils yield using hydro-distillation from needles, fruits and bark were $0.19 \%, 0.50 \%$ and $0.21 \% \mathrm{v} / \mathrm{w}$, respectively. The total number of identified compounds were 28, 29 and 27 in the essential oil obtained from needle, fruits and bark respectively (Table 1). The main constituents of the essential oil from needles were guaiol (12.7\%), limonene (11.4\%), and $\beta$-caryophyllene (7.6\%). Hmamouchi et al. (15) reported that the main component of the EOs obtained from $P$. pinea grown in Morocco was $\alpha$-pinene (37.0\%). $P$. pinea grown in Jordan showed that guaiol $(12.7 \%)$ as the major component, while the percentage of $\alpha$-pinene was $0.51 \%$ in the same sample. Amri et al. (16) reported that the limonene (54.1\%) was the main constituent in the Pinus pinea grown in Tunisia. The essential oil of needles of Pinus pinea grown in Greece was rich in limonene $(39.05 \%)$ and $\beta$-phellandrene (13.8\%). The other components were $\alpha$-pinene $(5.13 \%)$, guaiol $(2.79 \%)$, and $\beta$-pinene (2.65\%) (17). Pinus pinea grown in Italy and Turkey were rich in limonene and $\beta$-phellandrene content $(18,19)$. The percentage of limonene in Italy and Turkey were $58.9 \%$ and $55.0 \%$ respectively. While the percentage of $\beta$-phellandrene ranged from 6.7 to $7.4 \%$ The percentage of $\alpha$-pinene was $6.2 \%$ in Pinus pinea grown in Italy (18).

The major constituents of essential oil from fruits were limonene $(32.56 \%)$ and $\alpha$-pinene $(6.78 \%)$. Macchioni et al. (18) have reported that EO from cones contains mainly $61.6 \%$ of limonene in variety grown in Italy, while in the Jordanian variety the percentage of limonene was $32.56 \%$. The percent of $\alpha$-pinene $(19.4 \%)$ was also higher than the Jordanian variety $(6.78 \%)$. The other constituents present were $\beta$-caryophyllene $(2.8 \%), \beta$-pinene $(2.1 \%), \alpha$-terpineol $(1.4 \%)$, longifolene $(1.3 \%)$. In Turkey, Tumen et al. reported that EO of cones contained mainly limonene and $\beta$-phellandrene which 
Table 1. Chemical composition of essential oils from needles, fruits and barks of Pinus pinea grown in Jordan.

\begin{tabular}{|c|c|c|c|c|c|c|}
\hline Rt & RRI & RI & Compound & \multicolumn{3}{|c|}{ Relative percent content } \\
\hline & & & & Needles & Fruit & Bark \\
\hline 6.2 & 933 & 932 & $\alpha$-pinene ${ }^{a, c}$ & 0.51 & 6.78 & 0.48 \\
\hline 7.5 & 977 & 977 & Sabinene ${ }^{a, c}$ & 0.40 & 1.13 & - \\
\hline 7.8 & 988 & 988 & $\beta$-pinene ${ }^{a, c}$ & 0.36 & 4.66 & 0.37 \\
\hline 9.1 & 1024 & 1024 & $p$-cymene ${ }^{a, c}$ & - & 0.88 & - \\
\hline 9.3 & 1031 & 1030 & Limonene ${ }^{a, c}$ & 11.42 & 32.56 & 14.83 \\
\hline 9.9 & 1044 & 1044 & E-ocimene ${ }^{a, c}$ & 0.77 & - & - \\
\hline 11.6 & 1089 & 1089 & $p$-cymenene ${ }^{f}$ & - & 1.04 & - \\
\hline 12.9 & 1120 & 1121 & E- $p$-Mentha-2,8-diene-1-ol ${ }^{a, d}$ & - & - & - \\
\hline 13.1 & 1125 & 1125 & E-verbenol ${ }^{a, d}$ & - & 0.53 & - \\
\hline 13.3 & - & 1129 & $\alpha$-campholenal ${ }^{a, d}$ & - & 0.83 & - \\
\hline 13.5 & 1137 & 1135 & Z-p-Mentha-2,8-diene-1-ol ${ }^{a, d}$ & - & 0.65 & - \\
\hline 13.7 & 1140 & 1140 & E-pinocarveol ${ }^{a, d}$ & - & 1.19 & - \\
\hline 13.9 & 1145 & 1145 & Z-verbenol ${ }^{a, d}$ & - & 1.48 & - \\
\hline 14.6 & 1160 & 1160 & Pinocarvone ${ }^{a, d}$ & - & 0.71 & - \\
\hline 16.0 & 1195 & 1194 & $\alpha$-terpineol ${ }^{a, d}$ & 1.04 & 1.62 & 0.49 \\
\hline 16.6 & 1206 & 1206 & Verbenone $^{a, d}$ & - & 1.26 & - \\
\hline 17.0 & 1217 & 1218 & E-carveol ${ }^{a, d}$ & - & 2.87 & 0.63 \\
\hline 17.6 & 1235 & 1228 & Thymol methyl ether ${ }^{a, d}$ & 1.61 & 1.31 & 0.71 \\
\hline 18.2 & 1242 & 1242 & Carvone $^{a, d}$ & - & 1.72 & 0.61 \\
\hline 19.9 & 1286 & 1282 & Bornyl acetate ${ }^{a, d}$ & - & 0.99 & - \\
\hline 22.0 & 1333 & 1332 & $\delta$-elemene ${ }^{b, c}$ & 0.62 & - & - \\
\hline 22.6 & 1353 & 1346 & $\alpha$-longipinene ${ }^{b, c}$ & 0.80 & 0.99 & 2.12 \\
\hline 25.0 & 1402 & 1402 & Methyl eugenol ${ }^{d f}$ & 0.21 & - & - \\
\hline 25.2 & 1411 & 1405 & Longifolene $^{b, c}$ & 1.05 & 2.35 & 7.51 \\
\hline 25.5 & 1415 & 1415 & $\beta$-caryophyllene $b, c$ & 7.61 & 2.31 & 16.51 \\
\hline 25.6 & 1419 & 1417 & Aromadendrene ${ }^{b, c}$ & - & - & - \\
\hline 26.7 & - & 1443 & 6,9 -guaiadiene $b, c$ & 1.66 & - & - \\
\hline 26.7 & 1445 & 1445 & $\gamma$-muurolene $e^{b, c}$ & - & - & 0.29 \\
\hline 27.2 & - & 1457 & $\alpha$-humulene ( $\alpha$-caryophyllene) $)^{b, c}$ & 1.97 & 0.61 & 2.97 \\
\hline 28.0 & 1478 & 1476 & Germacrene-D $\mathrm{D}^{b, c}$ & 5.52 & 0.88 & 1.28 \\
\hline 28.3 & 1479 & 1482 & $\delta$-selinene ${ }^{b, c}$ & 4.14 & - & 0.88 \\
\hline 28.5 & 1490 & 1488 & $\mathrm{Z}$ - $\beta$-guaiene ${ }^{b, c}$ & 2.70 & - & - \\
\hline 28.6 & 1494 & 1494 & $\alpha$-muurolene $\mathrm{e}^{b, c}$ & 0.27 & - & 0.32 \\
\hline 29.3 & - & 1509 & Phenol,2,4-bis (1,1-dimethylethyl) ${ }^{d f}$ & - & - & 0.72 \\
\hline 29.6 & 1497 & 1513 & $\delta$-cadinene ${ }^{b, c}$ & 1.01 & - & 0.36 \\
\hline 30.7 & - & 1543 & E- $\alpha$-bisabolene ${ }^{b, c}$ & 0.64 & - & 0.49 \\
\hline 32.0 & 1576 & 1576 & Caryophyllene oxide $^{b, d}$ & 1.56 & 3.73 & 11.83 \\
\hline 32.6 & 1592 & 1591 & Guaiol $b, d$ & 12.70 & 1.22 & 3.13 \\
\hline 32.8 & 1592 & 1598 & Longiborneol ${ }^{b, d}$ & - & - & 1.18 \\
\hline 33.1 & 1606 & 1603 & Humulene epoxide II $^{b, d}$ & - & - & 1.64 \\
\hline 33.4 & - & 1614 & Rosifoliol ${ }^{b, d}$ & 0.73 & - & - \\
\hline 33.5 & 1617 & 1617 & 10-epi- $\gamma$-eudesmol ${ }^{b, d}$ & 2.36 & - & - \\
\hline 33.8 & - & 1625 & Humulane-1,6-dien-3-ol ${ }^{b, d}$ & - & - & 0.52 \\
\hline
\end{tabular}


Table 1. Continued.

\begin{tabular}{|c|c|c|c|c|c|c|}
\hline \multirow[t]{2}{*}{ Rt } & \multirow[t]{2}{*}{ RRI } & \multirow[t]{2}{*}{ RI } & \multirow[t]{2}{*}{ Compound } & \multicolumn{3}{|c|}{ Relative percent content } \\
\hline & & & & Needles & Fruit & Bark \\
\hline 33.9 & 1626 & 1626 & $\gamma$-eudesmol ${ }^{b, d}$ & 0.83 & - & - \\
\hline 34.8 & 1650 & 1650 & $\alpha$-eudesmol ${ }^{b, d}$ & 5.19 & 1.49 & 2.24 \\
\hline 35.3 & 1669 & 1664 & 14-hydroxy-9-epi-E-caryophyllene ${ }^{b, d}$ & - & 1.33 & 1.61 \\
\hline 40.0 & 1794 & 1798 & Ethyl myristate ${ }^{d f}$ & 1.56 & - & - \\
\hline 44.9 & - & 1943 & Phthalic acid butyl hexyl ester ${ }^{d f}$ & - & - & 0.65 \\
\hline 46.3 & 1995 & 1982 & Manoyl oxide ${ }^{d e}$ & 3.61 & 1.03 & 1.21 \\
\hline \multicolumn{4}{|c|}{ TOTAL } & 72.89 & 78.16 & 75.61 \\
\hline \multicolumn{4}{|c|}{ Monoterpene hydrocarbon } & 13.47 & 46.00 & 15.68 \\
\hline \multicolumn{4}{|c|}{ Oxygenated monoterpene } & 2.64 & 15.18 & 2.44 \\
\hline \multicolumn{4}{|c|}{ Sesquiterpene hydrocarbon } & 28.01 & 7.14 & 32.73 \\
\hline \multicolumn{4}{|c|}{ Oxygentedsesquiterpene } & 23.38 & 7.77 & 22.17 \\
\hline \multicolumn{4}{|c|}{ Diterpene } & 3.61 & 1.03 & 1.21 \\
\hline \multicolumn{4}{|c|}{ Nonterpene } & 1.77 & 1.04 & 1.37 \\
\hline
\end{tabular}

Rt: Retention time (in minutes), RRI: Relative retention indices, RI: retention indices, Concentration of constituents reported as Mean percent of triplicate analysis of 3 samples, —Not present, ${ }^{a}$ monoterpene, ${ }^{b}$ sesquiterpene, hydrocarbon, ${ }^{d}$ oxygenated, ${ }^{e}$ diterpene, ${ }^{f}$ nonterpene

Table 2. Antibacterial evaluation of essential oils obtained from needles, fruits and bark of Pinus pinea grown in Jordan.

\begin{tabular}{|c|c|c|c|}
\hline \multirow{2}{*}{ Sample } & \multicolumn{3}{|c|}{ Zone of inhibition $(\mathrm{mm})$} \\
\cline { 2 - 4 } & S. aureus & E. coli & K. pneumoniae \\
\hline EO from needles (33\% essential oil in 30\% DMSO) & 12 & - & - \\
\hline EO from fruits (33\% essential oil in 30\% DMSO) & 19 & 7 & 7 \\
\hline EO from bark (33\% essential oil in 30\% DMSO) & 15 & - & - \\
\hline Control (30\% DMSO) & - & - & - \\
\hline Tobramycin (30 $\mu \mathrm{g})$ & & 28 & - \\
\hline Penicillin G (10 U) & 20 & - & - \\
\hline Lincomycin $(2 \mu \mathrm{g})$ & 31 & - & 38 \\
\hline Chloramphenicol $(30 \mu \mathrm{g})$ & - & - & - \\
\hline Cefaclor $(30 \mu \mathrm{g})$ & - & 20 & - \\
\hline
\end{tabular}

Diameter of disks were $6 \mathrm{~mm},(\mathrm{n}=2)$

Table 3. DPPH radical scavenging, ferrous ion chelating, $B$-carotene bleaching and SNP scavenging activity of essential oils from needles, fruits and barks of Pinus pinea.

\begin{tabular}{|c|c|c|c|c|}
\hline Sample & $\begin{array}{c}\mathrm{IC}_{50}(\mathrm{DPPH} \text { radical }) \\
\mu \mathrm{g} / \mathrm{mL}\end{array}$ & $\begin{array}{c}\mathrm{IC}_{50}\left(\mathrm{Fe}^{2+} \text { assay }\right) \\
\mu \mathrm{g} / \mathrm{mL}\end{array}$ & $\begin{array}{c}\mathrm{IC}_{50}(ß-\text { carotene } \\
\text { bleaching assay) } \mu \mathrm{g} / \mathrm{mL}\end{array}$ & $\begin{array}{c}\mathrm{IC}_{50}(\mathrm{SNP} \text { radical } \\
\text { scavenging activity) } \mu \mathrm{g} / \mathrm{mL}\end{array}$ \\
\hline EO from Needles & $45.1 \pm 1.5$ & $51.1 \pm 0.9$ & $110.5 \pm 1.3$ & $175.0 \pm 2.5$ \\
\hline EO from Fruits & $40.5 \pm 0.7$ & $48.0 \pm 1.1$ & $115.4 \pm 2.1$ & $185.1 \pm 1.9$ \\
\hline EO from Bark & $48.4 \pm 1.2$ & $55.0 \pm 0.5$ & $138.2 \pm 2.3$ & $201.2 \pm 1.7$ \\
\hline Ascorbic acid & $5.0 \pm 0.4$ & - & - & - \\
\hline Rutin & - & $7.5 \pm 0.5$ & $42.4 \pm 1.2$ & - \\
\hline Quercetin & - & - & - & $55.4 \pm 0.8$ \\
\hline
\end{tabular}

Values are expressed as mean $\pm \operatorname{SD}(n=3)$ 
constitutes around $69.5 \%$ of essential oil (20). The yield of oil from $P$. pinea bark was $0.2 \%(\mathrm{v} / \mathrm{w})$. The results showed that $\beta$-caryophyllene $(16.5 \%)$ as the major compound. The other constituents identified were limonene $(14.83 \%)$, caryophyllene oxide (11.83\%) and longifolene (7.51\%). This difference or variations in the concentration may be due to their geographical location, climatic condition, time of collection and other factors.

\section{Antimicrobial activity}

EOs of $P$. pinea showed appreciable antibacterial activity compared to the standards on tested microorganisms. EOs obtained from needles, fruits and bark exhibited significant antibacterial activity against $S$. aureus, whereas the EOs obtained from fruit showed weak activity against E. coli and $K$. pneumoniae. The EOs obtained from other parts did not exhibit any activity against $E$. coli and $K$. pneumoniae (Table 2). The resistance of Gramnegative bacteria against essential oils (as we see with $E$. coli and $K$. pneumoniae) may be related to the presence of hydrophilic outer membrane surrounding the cell wall that prevents the EO's components from diffusing into the cell wall and causing its inhibitory action (21). There is a significant difference between the present results and the results reported earlier. Hmamouchi et al. (15) reported that EOs of needles of $P$. pinea grown in Morocco have antibacterial activity against Staphyloccocus aureus, Escherichia coli and Klebsiella pneumoniae when compared to our results that showed EO just inhibiting $S$. aureus without any antibacterial activity on E. coli and K. pneumoniae (15). Similar observations were made by Demirci et al. (19) who reported that EOs obtained from needles of $P$. pinea grown in Turkey had antibacterial activity against $E$. coli and $S$. aureus, whereas our results showed that this EO has antibacterial activity against $S$. aureus only.

\section{Antioxidant activities}

The DPPH scavenging activity of the sample was concentration-dependent. In the examined essential oils from various parts of $P$. pinea were capable of scavenging DPPH radical in-vitro. The $\mathrm{IC}_{50}$ values are mentioned in Table 3. The $\mathrm{IC}_{50}$ values were ranged from 40.5 to $48.4 \mu \mathrm{g} / \mathrm{mL}$. Regarding the $\mathrm{Fe}^{2+}$ Chelating assay the $\mathrm{IC}_{50}$ values were ranged from $48.0 \mu \mathrm{g} / \mathrm{mL}$ to $55.0 \mu \mathrm{g} / \mathrm{mL}$. The examined essential oils exhibited weak NO radical scavenging activity with mean $\mathrm{IC}_{50}$ value of 175.0 (EO from needles), 185.1 (EO from fruits) and 201.2 $\mu \mathrm{g} / \mathrm{mL}$ (EO from bark). The $\mathrm{IC}_{50}$ of quercetin was
$55.4 \pm 0.8 \mu \mathrm{g} / \mathrm{mL}$. The examined essential oils were also effective in preventing the bleaching of $\beta$ carotene using linoleic acid. The $\mathrm{IC}_{50}$ of the examined essential oils were ranged from 110.5 to 138.2 $\mu \mathrm{g} / \mathrm{mL}$, while the $\mathrm{IC}_{50}$ of rutin was $42.4 \pm 1.2 \mu \mathrm{g} / \mathrm{mL}$. These activities might be due to the presence of phenolic constituents present in the essential oils obtained from needles, fruits and bark. Yener et al. (22) reported that the chelating activity of the needles EO of this species was $17.6 \pm 0.1 \%$ at a concentration of $1 \mathrm{mg} / \mathrm{mL}$. The reported antioxidant activity was less significant as compared to the antioxidant activity of essential oil of $P$. brutia, $P$. halepensis, and $P$. nigra. The reported $\mathrm{IC}_{50}$ values of essential oil against DPPH radical ranged from 0.2 to $1.0 \mathrm{mg} / \mathrm{mL}$ (22).

\section{CONCLUSION}

The composition of the essential oils from needles, fruits and bark of $P$. pinea L. grown in Jordan were studied and the results indicated that the main component and the concentration of the constituents varied when compared with the same species grown in different or distributed in different geographical and climatic conditions. This difference or variations in the concentration may be due to their geographical location, climatic condition, time of collection and other factors. The studies indicated that the essential oil from fruits of $P$. pinea have significant antibacterial activity against $S$. aureus, while essential oils from fruits, needles and bark exhibited significant antioxidant activity, which may be due to terpene and other compounds. The plant may be further exploited for its active compounds and its therapeutic potentials, as there is a growing interest in new natural antioxidants and antibacterial compounds to replace the synthetic compounds that are being used in food, cosmetic and in pharmaceutical industries.

\section{Acknowledgments}

The authors would like to thank, Prof. Dr. Sari Hamdan, President, Al-Ahliyya Amman University, Amman for encouragement and constant motivation. The authors would also like to thank, Dean of Faculty of Pharmacy, Allied Medical Sciences and Scientific Research, Al-Ahliyya Amman University, Amman, Jordan for their support during the research work. Authors wish to thank Dr. Fayrouz Abousweilem, Department of Business for proof reading and editing of the manuscript. 


\section{Conflict of interest}

The authors declare no conflicts of interest.

\section{REFERENCES}

1. Dob T., Berramdane T., Chelgoum, C.: Comptes Rendus Chimie. 8, 1939 (2005).

2. Chambel M., Climent J., Pichot C., Ducci F.: Mediterranean Pines (Pinus halepensis Mill. and brutia Ten.), in Forest Tree Breeding in Europe. Managing Forest Ecosystems, Pâques L. Eds., Vol 25. pp. 229-265, Springer, Dordrecht 2013.

3. Abad Vinas R., Caudullo G., Oliveira S., de Rigo, D.: Pinus pinaster in Europe: distribution, habitat, usage and threats. In European Atlas of Forest Tree Species. San-Miguel-Ayanz, J., de Rigo, D., Caudullo, G., Houston Durrant, T., Mauri, A. Eds., pp. 130-131. Publication. Office EU, Luxembourg 2016.

4. Guarrera B.: Le piante del Lazio nell'uso terapeutico, alimentare, domestico, religioso e magico. Censimento del patrimonio forestale del Lazio, Vol 1. Dip. Biol. Veget., Roma 1994 (Book in Italian language).

5. Saab A.M., Guerrini A., Sacchetti G., Maietti S., Zeino M. et al.: Planta Med. 78, 1927 (2012).

6. Nasri N., Tlili N., Triki S., Elfalleh W., Chéraif I., Khaldi A.: J. Essent. Oil Res. 23, 15 (2011).

7. Prochazkova D., Bousova I., Wilhelmova N.: Fitoterapia 82, 513 (2011).

8. Yazdanparast R., Bahramikias S., Ardestani A.: Chem. Bio. Interact. 172, 176 (2008).
9. Lee M.T., Lin W.C., Yu B., Lee T.T.: AsianAustralas. J. Anim. Sci., 30, 299 (2017).

10. Naik R.R., Shakya A. K., Khalaf N.A., Abuhamdah S., Oriquat G.A., Maraqa A.: Jordan J. Pharm. Sci. 8, 181 (2015).

11. Chua M.T., Tung Y.T., Chang S.T.: Bioresour. Technol. 99, 1918 (2008).

12. Abuhamdah S., Abuhamdah R., Shakya A.K., Al-Olimat S.M., Chazot P.: Afr. J. Pharm. Pharmacol. 8, 1235 (2014).

13. LimY.Y., Quah E.P.L.: Food Chem. 103, 734 (2007).

14. Van den Dool H., Kratz P.D.: J. Chromatogr. 11, 436 (1963).

15. Hmamouchi M., Hamamouchi J., Zouhdi M., Bessiere J.M.: J. Essent. Oil Res. 13, 298 (2001).

16. Amri I., Gargouri S., Hamrouni L., Hanana M., Fezzani T., Jamoussi B.: J. Pest Sci. 85, 199 (2012).

17. Roussis V., Petrakis P.V., Ortiz A., Mazomenos B.E.: Phytochem. 39, 357 (1995).

18. Macchioni F., Cioni P., Flamini G., Morelli I., Maccioni S., Ansaldi M.: Flavour Fragr. J. 18, 139 (2003).

19. Demirci F., Bayramiç P., Göger G., Demirci B., Başer K.H.C.: Nat. Vol. Essent. Oils 2, 39 (2015).

20. Tumen I., Hafizoglu H., Kilic A., Donmez I.E., Sivrikaya H., Reunanen M.: Molecules 15, 5797 (2010).

21. Raho G.B.: J. Coast. Life Med. 2, 651 (2014).

22. Yener H.O. Saygideger S.D., Sarikurkcu C., Yumrutas O.: J. Essent. Oil Bear. Plants 17, 295 (2014).

Received: 12.04. 2019 